\title{
CASE STUDY: THE LIGNOCELLULOSIC COMPONENTS INTERFERENCES IN THE THERMAL BEHAVIOR OF BRAZILIAN SAVANA BIOMASS
}

\author{
M. R. da S. Miranda ${ }^{a}$, \\ M. G. Guimarães ${ }^{b}$, \\ N. A. Viana ${ }^{b}$, \\ N. N. Moura ${ }^{b}$, \\ B. S. Chaves ${ }^{c}$, \\ ABSTRACT \\ The residual biomass has become increasingly important in the energy \\ scenario due to its energetic potential and easy acquisition in isolated \\ communities. The heterogeneous nature of biomass makes the analysis of its \\ composition a relevant factor in the development of thermochemical \\ processes. Several researchers show that understanding this heterogeinidade \\ of biomass can be a strategy for optimization and search efficiency of \\ thermochemical processes, since it is possible to predict the results and in \\ addition, the reactor design based on the characteristics of biomass. In this \\ context, the purpose of this work was to study the behavior of three biomass \\ of the Brazilian savana - Dipteryx alata (baru), Hymenaea stigonocarpa \\ (jatobá-do-cerrado) and Caryocar brasiliense (pequi), comparing the \\ and C. A. G. Veras \\ lignocellulosic results with the thermal behavior obtained by \\ thermogravimetric analysis. The analysis were compared with results of \\ several researchers, confirming that those analysis are parameters that \\ influence the yield of the desired product. The results of this work elucidate \\ that the moisture and extractives content of pequi is greater than the other \\ biomass and that the temperature peak of cellulose and lignin from all \\ biomass in this study are quite close. However, the hemicellulose's \\ temperature peak of pequi is lower than baru and jatobá's temperature peak. \\ Moreover, the results showed that the composition of the lignocellulosic \\ biomass is an extremely important factor in selecting the greater reactivity \\ material. \\ _miranda20@yahoo.cr_ons \\ Instituto de Química \\ Campus Darcy Ribeiro \\ Brasília-DF, Brasil \\ ${ }^{\mathrm{c}}$ Serviço Florestal Brasileiro - SFB \\ Laboratório de Produtos Florestais \\ SCEN Trecho 2 - Ed. Sede \\ Brasília-DF, Brasil \\ Received: April 02, 2016 \\ Revised: May 16, 2016 \\ Accepted: June 16, 2016 \\ Keywords: biomass composition, bioenergy, baru, jatobá, pequi
}

\section{NOMENCLATURE}

ASTM American Society for Testing and Materials

$\mathrm{dm} / \mathrm{dt}$ derivative of the weight loss versus time, $\min ^{-1}$

DPP/UnB Decanato de Pesquisa e Pós-Graduação / Universidade de Brasília

FAPDF Fundação de Apoio à Pesquisa do Distrito Federal

HHV Higher Heat Value, $\mathrm{MJ} / \mathrm{Kg}$

HPLC High Performance Liquid Chromatography

NBR Brazilian Standard Reference

$\mathrm{N}_{2} \quad$ Nitrogen

$\mathrm{O}_{2} \quad$ Oxygen

SFB Serviço Florestal Brasileiro

T Temperature, ${ }^{\circ} \mathrm{C}$
TAPPI Technical Association of the Pulp and Paper Industry

\section{Greek symbols}

$\begin{array}{ll}\alpha & \text { heating rate, }{ }^{\circ} \mathrm{C} / \mathrm{min} \\ \rho & \text { energy density, } \mathrm{Kcal} / \mathrm{m}^{3}\end{array}$

\section{INTRODUCTION}

The biomass is currently considered as a potential source of energy. Biomass utilization has becoming important due to the availability and versatility of existing biomass and also for being a sustainable source (Tilman et al., 2006). The biomass 
from industrial residues is one of the most studied biomasses, given that the industries have shown concern with the disposal of their residues and also because the sustainability issue is now matter of survival for the future's guarantee. In this context, three industrial residues were chosen to be studied in this paper - baru, jatobá e pequi, which are wastes/residues of extractive activity in the Brazilian savana.

The baru (Dipterix alata Vog.) is an arboreous vegetal specie, belonging to the LeguminosaePapilionoideae family. The baru tree has a lifespan around 60 years and has its early fruiting at about 6 years. For practical purposes, with respect to the commercial use, the baru tree presents a productive crop every two years (Carraza et al., 2010).

The jatobá-do-cerrado (Hymenaea stigonocarpa Mart.) is a tree that can normally reach up to 15 meters high, with records of up to 40 meters. The tree begins to bear fruits with 8-10 years. A tree does not usually bear fruits every year. Whereas some trees produce a small amount of fruits, others can produce up to 2,000 fruits. Nonetheless, the average is 800 fruits per tree. The jatobá's bark has approximately $40 \%$ water in its composition (<www.cpac.embrapa.br> Acesso em 04/06/2015).

The pequi (Caryocar brasiliense) is part of one of the most important Cerrado's vegetal species family, belonging to the Caryocaraceae family and to the Caryocar gender. The pequi tree production, from seedings produced from seeds, starts 4 to 5 years after planted. The yield of pulp oil is $30 \%$ to $40 \%$ by fruit weight. In 1 hectare there is, approximately, a productivity of 1,200 boxes of fruit per year. Each hectare of crop produces up to 3,200 liters of oil, and each plant provides, on average, 6,000 fruits per year (<www.agencia.cnptia.embrapa.br/gestor/agroenergia /arvore/CONT000fbl23vmz02wx5eo0sawqe3egcicvo. html > Acesso em 04/06/2015).

The cellulose, hemicellulose and lignin percentages will depend on the biomass in study and the thermal degradation process is mainly influenced by the biomass composition. Thus, it is necessary to know the lignocellulosic components, given the importance to predict effectiveness of the biomass conversion process (Perez et al., 2002; Faravelli et al., 2010). These organic substances contained in the biomass can be converted into heat an energy without contributing to the emission of $\mathrm{CO}_{2}$. This fact allows the biomass to work as a carbon neutral power source. Therefore, it has become a very important energy source in recent decades (Pang et al., 2013). The lignin has an important role in the formation of coal, since the lignin acts in the second stage of thermal decomposition of biomass in an oxidizing atmosphere (Demirbas, 2001; Shen et al., 2009). The high ash content is associated with the lignin content. High ash contents jeopardize the equipment with inlaid in the pipelines and they can also absorb heat causing their fusion. As a result, the ash content can clog and wear out the construction material of the reactor or furnace. Therefore, the smaller the ash content, the lower the residual material inside the burning equipment (Ollero et al., 2003; Gilbert et al., 2009; Kleinlein, 2010).

Even though biomass has been used as an energy source for many years, it is still important to understand the thermal behavior of biomass in order to ensure an efficient use (Pang et al., 2014). It is possible to predict the yield and composition of pyrolysis products of any biomass, if its composition is known (Stefanidis et al., 2014). Several authors have studied the biomass composition in the literature however, few of them have studied the effect of the major components of the thermochemical conversion process (Raveendra et al., 2014; Yang et al., 2006; Worasuwannarak et al., 2007; Wang et al., 2008). Due to the variations in the chemical composition, the difference in reactivity of biomass should be better understood in order to optimize the process to obtain fuels and chemicals with high selectivity and efficiency (Carrier et al., 2011).

There are few studies regarding the pyrolisys of these biomasses and also few studies predicting the type of product and its yield trough the composition of biomass are even more scarce (Silveira, 2012). According to that, this work aims to analyze the contributions of hemicellulose, cellulose and lignin for the thermal behavior of three Brazilian savana biomass - baru, jatobá and pequi, in order to understand the influence of those biomass on the thermochemical process.

\section{MATERIALS AND METHODS}

- Origin of the studied biomass: the experiment was conducted with the core of pequi without pulp, peel of baru fruit and bark of the jatobá tree from a fruit extraction of a plantation located in the state of Goiás, Midwest region of Brazil, which belongs to COOPCERRADO (Rede de Comercialização Solidária de Agricultores Familiares e Extrativistas do Cerrado - Empório do Cerrado). (<www.emporiodocerrado.org.br/pt-br/documentos/ artigo-rede-um-novo-protagonismo-social.pdf $>$ Acesso em 17/06/2015).

- Extractives content: The methodology used for the oil extraction was the policies standart TAPPI 204 om-88 Technical association of the pulp and paper industry, with adaptations (TAPPI - T204);

- Ash content: The methodology used to determine the ash content without extractable, used the policies standart TAPPI T211 om-93 "Ash in wood, pulp, paper and paperboard combustion at $525^{\circ} \mathrm{C}$ " (TAPPI T 211);

- Lignin content: Laboratory procedures were adopted, LAP \#003 and LAP\#004, in accordance with Templeton \& Ehrman's article, 1995 (Templeton and Ehrman, 1995);

- Holocellulose content: It was calculated by difference. The percentage contents of total lignin and 
"free ash" were subtracted from 100\%;

- Moisture content: Immediate analysis according to the standard NBR 8112/86 with adaptations (NBR 8112/86);

- Thermal analysis (TG/DTG): The TG/DTG curves were obtained in a simultaneously analyser Model SDT 2960 from TA Instruments, with a heating rate $(\alpha)$ of $10^{\circ} \mathrm{C}$ min- 1 from room temperature $\left(\cong 25^{\circ} \mathrm{C}\right.$ ) up to $1000^{\circ} \mathrm{C}$ under a $100 \mathrm{~mL} / \mathrm{min}$ flow of synthetic air $\left(80 \pm 0.5\right.$ of $\mathrm{N}_{2}$ and $20 \pm 0.5$ of $\left.\mathrm{O}_{2}\right)$;

- Energy density: It was calculated from the product between the higher heating value - HHV, and the basic density - Bd (ASTM NBR 7190/1997).

\section{RESULTS AND DISCUSSION}

The physicochemical results of each biomass are elucidate in Table 1. It is possible to see that the results from moisture and extractives from pequi were far greater than the other biomass. A high moisture content interferes in the reaction since biomass spends more energy to initiate the process of decomposition of the components and the high content of extractive and ash inhibits the formation of certain compounds during the thermal decomposition (Gómez, 2002; Barakat et al., 2015). Some authors studied the effects of moisture and biochemical properties for the specific energy requirement. The lignin content according to the authors, was determined by Klason method and HPLC analysis was used to quantify monosaccharides (glucose, xylose, arabinose and uronic acids). They concluded that the higher the cellulose and lignin content, the lower is the energy required in the conversion processes (Barakat et al., 2015). On the other hand, they also concluded that the grater the amount of hemicellulose, the higher is the energy requirement. Another aspect to be noticed is related to the density of the material. It is noteworthy that one of the main objectives in the pyrolisys is to obtain products with an energy density higher than the original biomass. Therefore, the density is also a relevant factor to select the biomass (Bridgwater et al., 2008). It may be observed that there is a correlation between the energy density and the ash content. This fact was also verified by some authors that analyzed the ash content for the bagasse (Vieira et al., 2010).

Table 1. Physicochemical characterization.

\begin{tabular}{|c|c|c|c|}
\hline & Baru & Jatobá & Pequi \\
\hline Moisture & $12.02 \%$ & $11.56 \%$ & $28.56 \%$ \\
\hline $\begin{array}{c}\text { Energy } \\
\text { Density }(\rho)\end{array}$ & $\begin{array}{c}1,707.91 \\
\mathrm{kcal} / \mathrm{m}^{3}\end{array}$ & $\begin{array}{c}1,020.28 \\
\mathrm{kcal} / \mathrm{m}^{3}\end{array}$ & $\begin{array}{c}1,284.19 \\
\mathrm{kcal} / \mathrm{m}^{3}\end{array}$ \\
\hline Holocellulose & $65.82 \%$ & $60.69 \%$ & $60.65 \%$ \\
\hline Lignin & $31.82 \%$ & $38.07 \%$ & $36.99 \%$ \\
\hline
\end{tabular}

\begin{tabular}{|c|c|c|c|}
\hline Extractive & $21.65 \%$ & $13.25 \%$ & $40.73 \%$ \\
\hline Ash & $2.6 \%$ & $1.08 \%$ & $1.22 \%$ \\
\hline
\end{tabular}

Other authors have studied the effects of cellulose, hemicellulose and lignin to obtain gaseous products in the thermochemical conversion using pyrolysis or gasification of certain biomass. They noticed in their results that the biomass composition significantly affects the gas release profile. They concluded that high cellulose and hemicellulose content may result in higher concentrations of $\mathrm{CO}$ and $\mathrm{CO}_{2}$ and high lignin content results in a higher concentration of $\mathrm{CH}_{4}$ (Pasangulapati et al., 2012). Other researchers obtained their results that a biomass with high lignin content presents a high yield of coal. However, the complete combustion of lignin is achieved at higher temperatures, at $750^{\circ} \mathrm{C}$, and hence the maximum efficiency is achieved at higher temperatures, since the authors carried out pyrolysis on a microcalorimeter at a rate of $1{ }^{\circ} \mathrm{C} / \mathrm{s}$ (Dorez et al., 2014). With this assumption, it can be verified that there is a direct influence on the composition of biomass for the yield of products, for example, biomass with higher content of lignin should be used to obtain coal. Either way, it is important to emphasize that the composition and other parameters have influence, as previously mentioned.

Another important result is related to the carbon conversion efficiency. Some researches show that cellulose had a higher conversion efficiency of $99 \%$, followed by hemicellulose with $92 \%$ and finally lignin with $52 \%$. Carbon conversion efficiency is defined as the ratio of available carbon in gaseous and liquid products with respect to the total amount of available carbon in the biomass (Pasangulapati et al., 2012; Lv et al., 2004). Figures 1 and 2 show the results of weight loss of biomasses. It is possible to observe that the jatobá -Hymenaea stigonocarpa has a faster weight loss at the beginning of the reaction. Nonetheless, the pequi - Caryocar brasiliense after the decomposition of hemicellulose is replaced by a fester weight loss than other biomasses.

Figure 2 shows the results of the derivative of the thermogravimetric analysis at $20^{\circ} \mathrm{C} / \mathrm{min}$. It is possible to notice that the three biomasses picks are noticeable and that the decomposition of baru and jatobá are quite similar, however baru has a pick at $221,980^{\circ} \mathrm{C}$ that might be active cellulose or anhydrocellulose. Some authors studied the decomposition process and noticed that during the small weight loss before $250^{\circ} \mathrm{C}$, different reactions occur and may lead to the formation of an intermediate, sometimes called as active cellulose or anhydrocellulose. The active cellulose refers generally to an intermediate resulted of a partial depolymerization of cellulose, while the anhydrocellulose consists in an intermediate formed after the dehydration reactions (Van de Venden et al., 
2010; Scheirs et al., 2001; Banyasz et al., 2001).

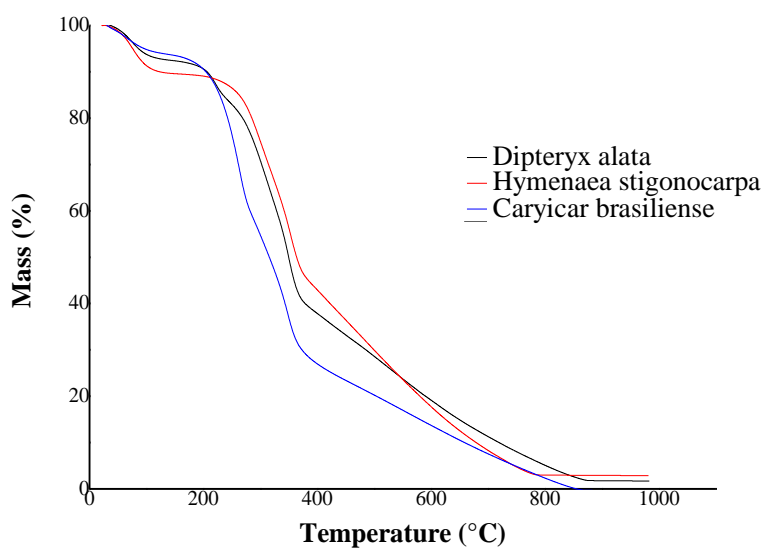

Figure 1 . Weight loss at $20^{\circ} \mathrm{C} / \mathrm{min}$.

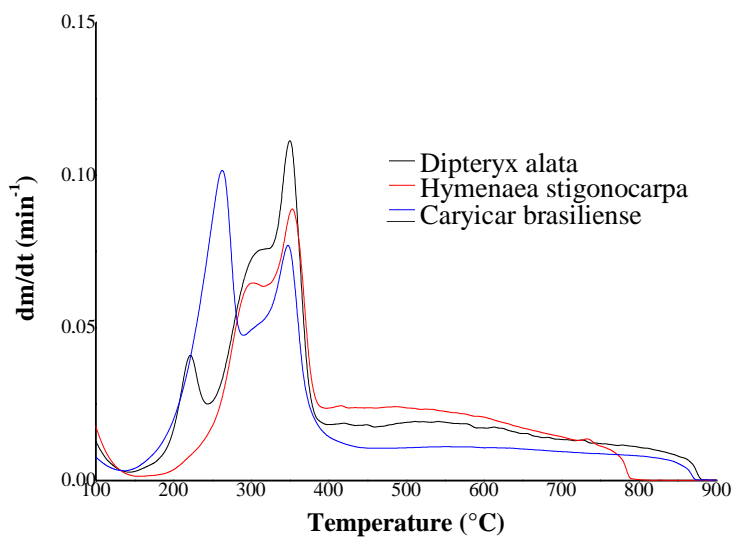

Figure 2. Derivative weight loss at $20^{\circ} \mathrm{C} / \mathrm{min}$.

It is important to emphasize that the difference between the curves of the two biomasses with pequi can be justified by the high oil content and high moisture of this biomass causing more complex and different reactions if compared with the others (Silveira, 2012). Furthermore, it is possible to notice that for the three biomasses, the beginning of decomposition occurs with approximately $\pm 90 \%$ by weight at a temperature of $\pm 200^{\circ} \mathrm{C}$, which is related to moisture loss and early devolatilization. This same fact was observed by other authors that studied the lignocellulosic components in their decomposition (Pasangulapati et al., 2012). Another justification for the appearance of a differentiated peak from baru would be the largest amount of holocellulose and lower amount of bauru's lignin if compared to other biomasses. Researchers evaluated the effect of age with respect of the chemical composition of eucalyptus wood and found that the older the tree, the smaller is the holocellulose content and the higher is the lignin content (Silva et al., 2005). The results of these authors show that baru tree is younger than jatobá because of the results of holocellulose an lignin shown in Table 1. Furthemore, an excess of cellulose results in unprotect and exposed cellulose fibers, which means that the fibers tend to form various inaccessible arrangements, once the cellulose has a tendency to agglomerate together. The cellulose fibers are contained inside the hemicellulose, which are intimately protected by lignin (Ding and Himmel, 2006: Ishizawa et al., 2009). These factors prove that the anatomical constitution influences the differences in the composition presented. The conversion of hemicellulose takes place between $250^{\circ} \mathrm{C}$ and $350^{\circ} \mathrm{C}$, the cellulose occurs between $330^{\circ} \mathrm{C}$ and $370^{\circ} \mathrm{C}$ and the lignin decomposition rate is between $300^{\circ} \mathrm{C}$ and $400^{\circ} \mathrm{C}$ ( $\mathrm{Lv}$ and $\mathrm{Wu}, 2012$; Yang et al., 2007; Shen et al., 2010; Wang et al., 2009). The pequi has the temperature peak of hemicellulose at $262,974^{\circ} \mathrm{C}$, and hence lower than the other biomasses. This is explained because the moisture content of pequi is higher than the other biomasses and, in addition, the pequi has higher oil content resulting in different reactions at the beginning, right after the loss of total moisture.

Some authors studied the lignocellulosic components and obtained by thermogravimetric analysis peak temperatures of $291^{\circ} \mathrm{C}$ for hemicellulose, $320^{\circ} \mathrm{C}$ for lignin and $356^{\circ} \mathrm{C}$ for cellulose. The authors concluded that the hemicellulose decomposes at a lower temperature followed by lignin and cellulose. Moreover, the authors also concluded that when the percentage of hemicellulose and cellulose is high, the temperature of its peak also increases, leading to a lower reactivity. Another important factor to be highlighted by the authors was that the peak of lignin is masked by overlapping of the other two components and that lignin decomposes over a wider temperature range and its peak varies in between hemicellulose and cellulose. Finally, they concluded that the lignocellulosic components do not act independent during the pyrolysis and hemicellulose is more reactive if compared to cellulose and lignin (Pang et al., 2014). The same conclusion was obtained on this work for the three biomasses, since the weight loss of lignin could not be noticed due to the overlap of the other components. In addition, the decompositions of each component followed the sequence hemicellulose, lignin and cellulose, as already mentioned by other authors. This is justified because the structural construction of the hemicellulose and lignin provides an inefficient packing, which decomposes at lower temperatures. On the other hand, the cellulose requires more energy to promote its combustion due to its crystal packing, so it decomposes at higher temperatures.

Besides all the above discussions, it is important to emphasize on the importance of higher calorific value of the final product. Many of the properties discussed above influence the potential energy, such as ashes. Some authors analyzed coal and high calorific value of the coal Eucalyptus spp resulted in $31.06 \mathrm{MJ} / \mathrm{kg} ; 13.40 \mathrm{MJ} / \mathrm{kg}$ for the peach pit coal; 31.17 MJ/kg for coal Hymenaea stigonocarpa; 22.74 
$\mathrm{MJ} / \mathrm{kg}$ for the coal castor bean meal, demonstrating that these results vary with the type of biomass and its properties (Barcellos, 2007; Vale et al., 2001; doumera et al., 2015). Thus, as a continuation of this work proposes perform pyrolysis and analyze the biomass with the greatest potential for energy generation, utilizing important information such as the characteristics described in this study.

\section{CONCLUSIONS}

Each material exhibits a particular characteristic when it is pyrolysed due to the portion of components that constitute them. The reactions occurring during the pyrolysis can be explained by the composition of the biomass, which can interfere in the energy required, in the types of gases produced, in the yield of coal and finally, in the process efficiency as a whole. The biomasses studied in this work present energy profile and composition to be utilized by various thermochemical processes, which can be employed in isolated communities for decentralization of power generation of energy, because their composition is heterogeneous and these residues are usually obtained through extractive communities.

\section{ACKNOWLEDGMENT}

To DPP/UnB, MCT/CNPq, CAPES, FINEP/CTInfra, FAPDF, Empório do Cerrado and SFB.

\section{REFERENCES}

ASTM, NBR 7190/1997, 1997, Associação Brasileira de Normas Técnicas. ABNT NBR 7190: Projeto de Estruturas de Madeira, Rio de Janeiro. (in Portuguese)

Banyasz, J. L., Li, S., and Lyons-Hart, J., 2001, Gas Evolution and the Mechanism of Cellulose Pyrolysis, Fuel, Vol. 80, pp. 1757-1763.

Barakat, A., Monlau, F., Solhy, A., and Carrere, H., 2015, Mechanical Dissociation and Fragmentation of Lignocellulosic Biomass: Effect of Initial Moisture, Biochemical and Structural Proprieties on Energy Requirement, Applied Energy, Vol. 142, pp. 240-246.

Barcellos, D. C, 2007, Caracterização do Carvão Vegetal através do Uso de Espectroscopia no Infravermelho Próximo, Doctoral Thesis, Universidade Federal de Viçosa, Viçosa, MG. (in Portuguese)

Bridgwater, C., Csernik, S., Dielbold, J., Meier, D., Oasmaa, A., Peacocke, C., Piskorz, J., and Radlein, D., 2008, Fast Pyrolysis of Biomass: a Handbook. Aston University, Bio-energy Research Group.

Carraza, L. R., and D’ávila, J. C. C., 2010, Manual Tecnológico de Aproveitamento Integral do Fruto do Baru (Dípteryx alata), 2ed. ISPN, BrasíliaDF. (in Portuguese)

Carrier, M., Loppinet-Serani, A., Denux, D.,
Lasnier, J.-M., Ham-Pichavant, F., Cansell, F., and Aymonier, C., 2011, Thermogravimetric Analysis as a New Method Todetermine the Lignocellulosic Composition of Biomass, Biomass and Bioenergy, Vol. 35, No. 1, pp. 298-307.

Demirbas, A., 2001, Relationships Between Lignin Contents and Heating Values of Biomass, Energy Convers, Manage, Vol. 42. No. 2, pp. 183188.

Ding, S.-Y., and Himmel, M. E., 2006, The Maize Primary Cell Wall Microfibril: a New Model Derived from Direct Visualization, Journal of Agricultural and Food Chemistry, Vol. 54, No. 3, pp. 597-606.

Dorez, G., Ferry, L., Sonnier, R., Taguet, A., and Lopez-Cuesta, J. M, 2014, Effect of Celulose, Hemicellulose and Lignina Contentes on Pyrolysis and Combustion of Natural Fibers, Journal of Analytical and Applied Pyrolysis, Vol. 107, pp. 323331.

Doumera, M. E., Arízagab, G. G. C., Silva, D. A., Yamamoto, C. I., Novotnye, E. H., Santos, J. M., Santos, L. O., Andrade, J. B., and Mangrich, A. S. 2015, Slow Pyrolysis of Different Brazilian Waste Biomasses as Sources of Soil Conditioners and Energy and for Environmental Protection, Journal of Analytical and Applied Pyrolysis, Vol. 113, pp. 434443.

Faravelli, T., Frassoldati, A., Migliavacca, G., and Ranzi, E., 2010, Detailed Kinetic Modeling of the Thermal Degradation of Lignins, Biomass Bioenergy, Vol. 34, No. 3, pp. 290-301.

Gilbert, P., Ryu, C., Sharifi, V., and Swithenbank, J., 2009, Effect of Process Parameters on Pelletisation of Herbaceous Crops, Fuel, Vol. 88 No. 8, pp. 1491-1497.

Gómez, E. O., 2002, Estudo da Pirólise Rápida de Capim Elefante em Leito Fluidizado Borbulhante Mediante Caracterização dos Finos de Carvão, Doctoral Thesis, FEAGRI, UNICAMP, Campinas, SP. (in Portuguese)

Ishizawa, C., Jeoh, T., Adney, W., Himmel, M., Johnson, D., and Davis, M., 2009, Can Delignification Decrease Cellulose Digestibility in Acid Pretreated Corn Stover, Cellulose, Vol. 16, No. 4, pp. 677-686.

Kleinlein, W. A, 2010, Caracterização Energética de Biomassas Amazônicas, Master Thesis, Universidade Federal do Pará, Programa de Pós Graduação em Engenharia Mecânica, Belém, PA. (in Portuguese)

Lv, P. M., Xiong, Z., Chang, J., Wu, C., Chen, Y., and Zhu, J., 2004, An Experimental Study on Biomass Air-Steam Gasification in a Fluidized Bed, Bioresource Technology, Vol. 95, No. 1, pp. 95-101.

Lv, G., and Wu, S., 2012, Analytical Pyrolysis Studies of Corn Stalk and its Three Main Components by TG-MS and Py-GC/MS, Journal of Analytical and Applied Pyrolysis, Vol. 97, pp. 11-18.

NBR 8112/86, 1986, Carvão Vegetal - Análise Imediata, ABNT. (in Portuguese) 
Ollero, P., Serrera, A., Arjona, R., and Alcantarilla, S., 2003, The $\mathrm{CO}_{2}$ Gasification Kinetics of Olive Residue, Biomass Bioenergy, Vol. 24, No. 2, pp. 151-161.

Pang, C. H., Gaddipatti, S., Tucker, G., Lester, E., and Wu, T., 2014, Relationship Between Termal Behaviour of Lignocellulosic Componentes and Properties of Biomass, Bioresource Techonology, Vol. 172, pp. 312-320.

Pang, C. H., Hewakandamby, B., Wu, T., and Lester, E., 2013, An Automated Ash Fusion Test for Characterisation of the Behaviour of Ashes from Biomass and Coal at Elevated Temperatures, Fuel, Vol. 103, pp. 454-466.

Pasangulapati, V., Ramachandriya, K. D., Kumar, A., Wilkins, M. R., Jones, C. L., and Huhnke, R. L., 2012, Effects of Celulose, Hemicellulose and Lignina on Thermochemical Conversion Characteristics of the Selected Biomass, Bioresource Technology, Vol. 114, pp. 663-669.

Perez, J., Muñoz-Dorado, J., De la Rubia, T., and Martinez, J., 2002, Biodegradation and Biological Treatments of Cellulose, Hemicellulose and Lignin: an Overview, International Microbiology, Vol. 5, pp. 53-63.

Raveendra, K., Ganesh, A., and Khilar, K. C., 1996, Pyrolysis Characteristics of Biomass and Biomass Components, Fuel, Vol. 75, pp. 987-998.

Scheirs, J., Camino, G., and Tumiatti., W., 2001, Overview of Water Evolution During the Thermal Degradation of Cellulose, European Polymer Journal, Vol. 37, pp. 933-942.

Shen, D. K., Gu, S., and Bridgwater, A. V., 2010, Study on the Pyrolytic Behaviour of XylanBased Hemicellulose Using TG-FTIR and Py-GCFTIR, Journal of Analytical and Applied Pyrolysis, Vol. 87, pp. 199-206.

Shen, D. K., Gu, S., Luo, K. H., Bridgwater, A. V., and Fang, M. X., 2009, Kinetic Study on Thermal Decomposition of Woods in Oxidative Environment, Fuel, Vol. 88, No. 6, pp. 1024-1030.

Silva, J. C., Matos, J. L. M., Oliveira, J. T. S. and Evangelista, W. V., 2005, Influência da Idade e da Posição ao Longo do Tronco na Composição Química da Madeira de Eucalyptus Grandis Hill ex. Maiden, Sociedade de Investigações Florestais, Vol. 29, No. 3, pp. 455-460. (in Portuguese)

Silveira, I. S., 2012, Pirólise de Pequi. Avaliação do Rendimento e da Caracterização Físico-Químico da Fração Orgânica, Master Thesis, Pos-Graduação em Agroenergia-UFT, Palmas, TO. (in Portuguese)

Stefanidis, S. D., Kalogiannis, K. G., Lliopoulou, E. F., Michailof, C. M., Pilavachi, P. A., and Lappas, A. A., 2014, A Study of Lignocellulosic Biomass Pyrolysis via the Pyrolysis of Cellulose, Hemciellulose and Lignin, Journal of Analytical and Applied Pyrolysis, Vol. 105, pp. 143-150.

Tilman, D., Hill, J., and Lehman, C., 2006, Carbon-Negative Biofuels from Low-Input High-
Diversity Grassland Biomass, Science, Vol. 314, No. 5805, pp. 1598-1600.

TAPPI - T 204 om-88. (s.d.), 2007, TAPPI - T 204 om-88 - Solvent Extratives of Wood and Pulp., Technical Association of the Pulp and Paper Industry.

TAPPI - T 211 om-93. (s.d.), 2002, TAPPI - T 211 - Ash in Wood, Pul, Paper and Paperboard: Combustion at $525^{\circ} \mathrm{C}$, Technical Association of the Pulp and Paper Industry.

Templeton, D., and Ehrman, T., 1995, Determination of Acid-Insoluble Lignin in Biomass LAP-003 e Determination of Acid-Soluble Lignin in Biomass - LAP-004, National Renewable Energy Laboratory, NREL.

Vale, A. T. do, Costa, A. F. da, Gonçalves, J. C., and Nogueira, M., 2001, Relações Entre a Densidade Básica da Madeira, o Rendimento e a Qualidade do Carvão Vegetal de Espécies do Cerrado, Revista Árvore, Vol. 25, No. 1, pp. 89-95. (in Portuguese)

Van de Velden, M., Baeyens J., and Brems A., 2010, Fundamentals, Kinetics and Endothermicity of the Biomass Pyrolysis Reaction, Renew Energy, Vol. 35, pp. 232-242.

Vieira, B. C. N., Santos, K. G., Barrozo, M. A. S., Muttoni, N., and Murata, V. V., 2010, Estimativa da Energia de Ativação Global da Pirólise de Bagaço de Cana Empregando Métodos Isoconversionais, in: $X V$ Jorneq, Universidade Federal de Uberlândia. (in Portuguese)

Wang, G., Li, W., and Chen, B. H., 2008, TG Study on Pyrolysis of Biomass and its Three Components Under Syngas, Fuel, Vol. 87, pp. 552558.

Wang S., Wang K., and Liu Q., 2009, Comparison of the Pyrolysis Behavior of Lignins from Different Tree Species, Biotechnology Advances, Vol. 27, pp. 562-567.

Worasuwannarak, N., Sonobe, T., and Tanthapanichakoon, W., 2007, Pyrolysis Behaviors af Rice Straw, Rice Husk, and Corncob by TG-MS Technique, Journal of Analytical and Applied Pyrolysis, Vol. 78, pp. 265-271.

Yang, H., Yan, R., Chen, H., Zheng, C., and Lee, D., 2006, In-depth Investigation of Biomass Pyrolysis Based on Three Major Components: Hemicellulose, Cellulose and Lignin, Energy, Fuel, Vol. 20, pp. 388-393.

Yang, H, Yan, R, and Chen, H, 2007, Characteristics of Hemicellulose, Cellulose and Lignin Pyrolysis, Fuel, Vol. 86, pp. 1781-1788. 